\title{
PENGARUH PENAMBAHAN SARI BUAH NANAS (ANANAS COMOSUS) TERHADAP JUMLAH BAKTERI ASAM LAKTAT (BAL) DAN NILAI PH SOYGHURT
}

\author{
Emiliya Kusuma Wardani ${ }^{1}$, Siti Zulaekah ${ }^{2}$, Eni Purwani ${ }^{3}$ \\ ${ }^{1}$ RSUD Agats Jl. Misi No 1 Distrik Agats-Asmat, Kabupaten Asmat Provinsi Papua. \\ Email: 1emiliyakapoor@gmail.com \\ ${ }^{2,3}$ Program Studi Ilmu Gizi Fakultas Ilmu Kesehatan Universitas Muhammadiyah \\ Surakarta. Jl. A. Yani Tromol Pos I Pabelan Surakarta. \\ Email: ${ }^{2}$ siti.zulaekah@ums.ac.id, ${ }^{3}$ eni.purwani@ums.ac.id
}

\begin{abstract}
ABSTRAK
Penambahan sari buah nanas pada soyghurt dapat meningkatkan mutu organoleptik soyghurt. Sari buah nanas mengandung gula yang dapat meningkatkan aktivitas bakteri asam laktat (BAL). Sari buah nanas ditambahkan untuk memperbaiki citarasa soyghurt. Tujuan penelitian ini adalah untuk mengetahui pengaruh penambahan sari buah nanas terhadap jumlah bakteri asam laktat (BAL) dan nilai $\mathrm{pH}$ soyghurt. Penelitian dilakukan dengan konsentrasi sari buah nanas pada pembuatan soyghurt dengan variasi konsentrasi 0\%, 15\% dan 30\%. Hasil penelitian menunjukkan bahwa tidak ada pengaruh penambahan sari buah nanas terhadap jumlah bakteri asam laktat (BAL) soyghurt dan kecenderungan adanya pengaruh penambahan sari buah nanas terhadap nilai $\mathrm{pH}$ soyghurt. Jumlah bakteri asam laktat (BAL) tertinggi diberikan oleh soyghurt dengan penambahan sari buah nanas pada

konsentrasi $0 \%$ yaitu $288 \times 10^{6} \mathrm{CFU} / \mathrm{ml}$. Nilai $\mathrm{pH}$ tertinggi diberikan oleh soyghurt dengan penambahan sari buah nanas pada konsentrasi $0 \%$ yaitu 4,15 .
\end{abstract}

Kata Kunci: Bakteri asam laktat, $\mathrm{pH}$, sari buah nanas, soyghurt

\begin{abstract}
The addition of the pineapple juice on soyghurt can increase its organoleptic quality. The pineapple juice contains sugar that increasing the activity of lactic acid bacteria. The research aimed to determine the effect of pineapple juice added to the number of lactic acid bacteria and $\mathrm{pH}$ of soyghurt. The research was conducted with $0 \%, 15 \%$ and $30 \%$ of pineapple juice. The results showed that there was no effect of pineapple juice on the number of lactic acid bacteria of soyghurt. The significant effect revealed by $\mathrm{pH}$ of soyghurt. The highest number of lactic acid bacteria was given by soyghurt with the addition of pineapple juice $0 \%$, was $288 \times 10^{6} \mathrm{CFU} / \mathrm{ml}$ and the $\mathrm{pH}$ value of $0 \%$, which was 4.15 .
\end{abstract}

Keywords: Lactic acid bacteria, $\mathrm{pH}$, pineapple juice, soyghurt 


\section{PENDAHULUAN}

Fermentasi merupakan salah satu cara untuk memperpanjang umur simpan produk susu. Soyghurt merupakan fermentasi susu kedelai dengan bakteri asam laktat (BAL) yaitu bakteri Lactobacillus Bulgaricus dan Streptococcus Thermophillus (Irkin dan Eren, 2008). Penggunaan susu kedelai sebagai bahan baku pembuatan yoghurt telah banyak diteliti dan diproduksi. Pengembangan produk yoghurt berbasis kedelai ini didasarkan pada peningkatan jumlah konsumen yang memilih bahan pangan yang memberikan efek terhadap kesehatan (Drake dkk., 2000; Uzzan dan Labuza, 2004).

Kelemahan dari pembuatan yoghurt berbahan dasar susu kedelai dalam bentuk cair, antara lain kurang praktis karena membutuhkan waktu proses yang lama jika dirangkaikan dengan proses pembuatan yoghurt, serta yoghurt yang dihasilkan kurang konsisten sifat fisikokimianya dari setiap frekuensi pembuatan (Rauf dkk., 2011).

Rauf dkk. (2011) melaporkan hasil pembuatan yoghurt berbahan dasar tepung kedelai menunjukkan hasil viskositas dan stabilitas yang rendah. Jannah (2014) juga berpendapat bahwa saat ini sudah banyak inovasi yang dapat dilakukan untuk memperbaiki citarasa soyghurt yaitu dengan penambahan flavour buah-buahan. Penambahan sari buah nanas (Ananas Comosus) pada soyghurt dapat meningkatkan mutu organoleptik soyghurt. Efek pemberian sari buah nanas pada soyghurt akan mempengaruhi kekentalan, kekeruhan dan kadar padatan terlarut yang akan menentukan kualitas soyghurt tersebut. Perubahan jumlah BAL, $\mathrm{pH}$, dan keasamaan terjadi selama fermentasi. Selama proses fermentasi, laktosa diubah oleh bakteri asam laktat menjadi asam laktat. Perubahan ini akan mempengaruhi nilai $\mathrm{pH}$ soyghurt.

Tujuan dari penelitian ini adalah mengetahui pengaruh penambahan sari buah nanas terhadap jumlah bakteri asam laktat (BAL) dan nilai $\mathrm{pH}$ pada soyghurt.

\section{METODE PENELITIAN}

\section{Bahan}

Bahan utama pembuatan soyghurt yaitu menggunakan kacang kedelai yang diperoleh dari pasar tradisional di kota Surakarta. Buah nanas yang digunakan diperoleh dari pasar tradisional di kota Surakarta. Medium MRS agar yang digunakan diperoleh dari laboratorium biologi tanah, Fakultas Pertanian Universitas Sebelas Maret. Starter bakteri asam laktat yaitu Lactobacillus bulgaricus dan Streptococcus thermphillus yang digunakan diperoleh dari laboratorium mikrobiologi tanah, Fakultas Pertanian Universitas Gadjah Mada. Bahan lain seperti gula pasir dan tepung tapioka diperoleh dari pasar tradisional di kota Surakarta.

\section{Alat}

Peralatan yang digunakan terbagi atas dua kelompok, yaitu alat pengolahan dan alat analisis. Alat untuk pengolahan antara lain grinder, pengayak 80 mesh, timbangan digital, saringan, blender, dan kompor. Alat untuk menganalisis jumlah bakteri asam laktat (BAL) dengan metode hitungan cawan (Total Plate Count) pada medium MRS agar yang selanjutnya perhitungan jumlah mikroba menggunakan colony counter, sedangkan alat untuk menguji nilai $\mathrm{pH}$ menggunakan alat $\mathrm{pH}$ meter.

\section{Pembuatan Tepung Kacang Kedelai}


Pembuatan tepung kacang kedelai mengikuti prosedur Rauf dan Sarbini (2012) yang dimodifikasi. Biji kedelai dipilih dan dibersihkan dari kotoran. Kacang kedelai dicuci dan direndam selama 8 jam. Selanjutnya biji kacang kedelai direbus selama 15 menit dan dilakukan pengupasan pada kulit kacang kedelai, dilanjutkan dengan proses pengeringan menggunakan sinar matahari selama 3. Kacang kedelai kemudian digiling lalu diayak 80 mesh.

\section{Pembuatan Sari Buah Nanas}

Pembuatan sari buah nanas mengikuti prosedur Lesbani, A dkk. (2014). Buah nanas dikupas kulitnya kemudian dicuci. Buah nanas dipotong dan dihaluskan dengan penambahan air 1 liter air matang untuk $1 / 2 \mathrm{~kg}$ nanas. Selanjutnya buah nanas yang sudah halus diperas dengan menggunakan kain saring yang steril.

\section{Pembuatan Soyghurt}

Pembuatan soyghurt mengikuti prosedur Rauf dan Sarbini (2012). Tepung kedelai sebanyak 10\% (b/v) didispersikan dalam aquades. Kemudian ditambahkan glukosa sebanyak $10 \%$ (b/v) dan bahan penstabil (pati jagung) diaduk dengan menggunakan magnetic stirrer hingga homogen. Pasteurisasi dilakukan dalam air mendidih selama 20 menit. Setelah dingin ditambahkan sari buah nanas $0 \%$, $15 \%, 30 \%$ dan starter Streptococcus thermphillus dan Lactobacillus bulgaricus, masing-masing sebanyak 5\%. Selanjutnya diinkubasi pada suhu $37^{\circ} \mathrm{C}$ selama 24 jam.

\section{Uji Jumlah Bakteri Asam Laktat}

Uji jumlah bakteri asam laktat mengikuti prosedur Hidayat dkk. (2013). Metode hitung cawan (Total Plate Count) digunakan untuk menentukkan total BAL. Perhitungan total BAL dihitung pada penanaman media Man Rogosa and
Sharpe (MRS). Penghitungan total BAL diawali dengan sampel diencerkan dalam aquades steril dengan perbandingan 1:9. Pengenceran dilakukan $10^{-1}$ hingga $10^{-7}$. Pembuatan media cawan dilakukan dengan media MRS agar. Pembuatan MRS agar sebanyak 65,13 g dilarutkan ke dalam $1000 \mathrm{ml}$ aquades, kemudian larutan MRS agar di waterbath pada suhu $95^{\circ} \mathrm{C}$ hingga larut dan disterilkan dengan pada suhu $121^{\circ} \mathrm{C}$ selama 15 menit. Pembuatan media cawan dilakukan dengan $1 \mathrm{ml}$ sampel hasil pengenceran dimasukkan ke dalam cawan petri yang sudah berisi MRS agar. Pembuatan media cawan dilakukan dari pengenceran $10^{-6}$ sampai $10^{-7}$. Kemudian, cawan petri digerak-gerakkan membentuk angka 8, agar homogen. Setelah padat cawan petri tersebut diinkubasi dengan posisi terbalik pada suhu $37^{\circ} \mathrm{C}$ selama 48 jam.

\section{Uji Nilai pH}

Uji nilai $\mathrm{pH}$ mengikuti prosedur Hidayat dkk. (2013). Pengujian nilai pH dilakukan dengan menggunakan $\mathrm{pH}$ meter elektronik. Sebelum pH meter elektronik digunakan ujung katoda indikator dicuci dengan aquades, kemudian dibersihkan dengan tissue. Kemudian $\mathrm{pH}$ meter elektronik dikalibrasi dengan ujung katoda dicelupkan dalam larutan buffer 4 (Wahyudi, 2006). Kemudian ujung katoda dicelupkan dalam sampel soyghurt. Hasil pengukuran dibaca pada $\mathrm{pH}$ meter.

\section{Rancangan Penelitian}

Penelitian ini menggunakan rancangan acak lengkap. Terdapat tiga perlakuan konsentrasi penambahan sari buah nanas pada pembuatan soyghurt yaitu $0 \%, 15 \%$ dan $30 \%$. Hasil penilitian diuji menggunakan uji statistik one way anova satu arah jika data berdistribusi normal dan homogen jika terdapat pengaruh, maka dilanjutkan uji Duncan Multiple Range Test (DMRT) dengan taraf signifikansi 95\%. Uji statistik 
kruskall wallis jika data tidak berdistribusi normal serta tidak homogen.

\section{HASIL DAN PEMBAHASAN}

\section{Total Bakteri Asam Laktat Soyghurt} dengan Penambahan Sari Buah Nanas

Jumlah total BAL yang diuji menggunakan Kruskall Wallis yaitu nilai $\mathrm{p}=0,620$ menunjukkan bahwa perlakuan penambahan sari buah nanas tidak ada pengaruh nyata $(p>0,05)$ terhadap total BAL soyghurt. Pengaruh perlakuan konsentrasi sari nanas dapat dilihat pada Gambar 1.

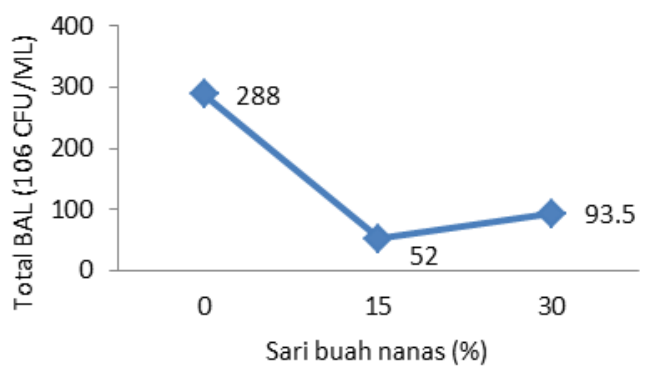

Gambar 1. Total BAL soyghurt dengan penambahan sari buah nanas

Data pada Gambar 1 dapat dilihat bahwa pada penambahan konsentrasi sari nanas $0 \%, 15 \%$, dan $30 \%$ terhadap jumlah BAL mengalami penurunan dan meningkat kembali pada konsentrasi sari buah nanas $30 \%$.

Total BAL yang didapatkan pada soyghurt dengan penambahan sari buah nanas tersebut termasuk tinggi. Hal ini disebabkan dari bakteri Lactobacillus bulgaricus dan Strepthococcus thermophilus yang saling mendukung dan bersinergi dalam perbanyak sel. Menurut Surono (2004) S. thermophilus dan $L$. bulgaricus saling mendukung. $S$. thermophilus menghasilkan asam piruvat, asam format dan $\mathrm{CO} 2$, serta asam folat yang menstimulir pertumbuhan $L$ bulgaricus. Sebagai imbalannya, $L$. bulgaricus akan melepas asam amino valin, glisin dan histidin yang diperlukan oleh S. thermophilus (Prayitno, 2006).

Berdasarkan Gambar 1 menunjukkan bahwa jumlah konsentrasi sari buah yang ditambahkan, jumlah BAL mengalami penurunan dengan meningkatnya penambahan kosentrasi sari buah nanas. Hal ini diduga disebabkan karena menurunnya $\mathrm{pH}$ dan meningkatnya keasaman. Menurut Shah (2000) faktor utama turunnya kelangsungan hidup organisme probiotik dikaitkan dengan adanya penurunan $\mathrm{pH}$ medium dan akumulasi asam organik sebagai hasil metabolit fermentasi. Mulyani (2008) menyatakan bahwa nilai $\mathrm{pH}$ menurun seiring dengan menurunnya aktivitas bakteri, ditandai dengan semakin berkurangnya jumlah BAL yang masih hidup.

Perubahan jumlah total BAL terjadi selama fermentasi. Proses fermentasi, laktosa diubah oleh bakteri asam laktat menjadi asam laktat. Meningkatnya total bakteri asam laktat dipengaruhi oleh nutrisi dalam tepung kedelai. Kumalasari, Nurwantoro dan Mulyani (2012) mengatakan bahwa sel-sel bakteri asam laktat mampu tumbuh dan membelah diri secara aksponensial sampai jumlah maksimum yang dipengaruhi oleh kondisi lingkungan dan nutrisi di dalam media. Pertumbuhan mikroba dalam bahan pangan erat kaitannya dengan media tumbuh yang tersedia untuk pertumbuhan mikroba di dalamnya.

\section{Nilai pH Soyghurt dengan Penambahan Sari Buah Nanas}

Nilai pH yang diuji menggunakan Kruskall Wallis yaitu p=0,102 menunjukkan bahwa perlakuan penambahan sari buah nanas memiliki kecenderungan adanya beda nyata ( $>>0,05)$ terhadap nilai $\mathrm{pH}$ soyghurt. Hasil 
pengaruh perlakuan konsentrasi sari nanas dapat dilihat pada Gambar 2.

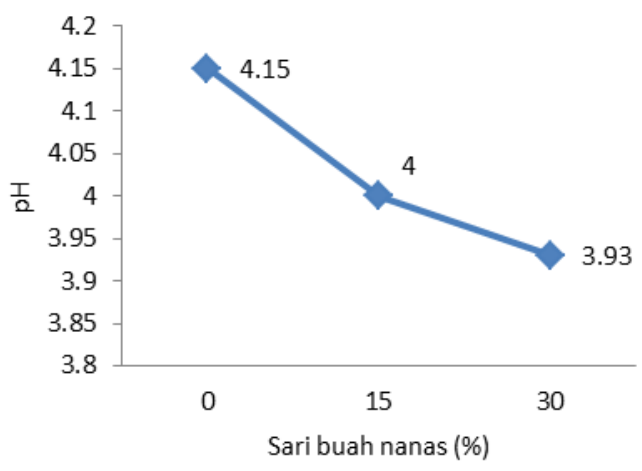

Gambar 2. Nilai pH soyghurt dengan penambahan sari buah nanas

Data pada Gambar 2 dapat dilihat bahwa penambahan konsentrasi sari buah nanas $0 \%, 15 \%$, dan $30 \% \mathrm{pH}$ soyghurt mengalami penurunan. Penurunan $\mathrm{pH}$ merupakan salah satu akibat dari proses fermentasi yang terjadi karena diproduksinya asam laktat yang berasal dari bakteri asam laktat.

Semakin banyak asam laktat yang terbentuk maka nilai $\mathrm{pH}$ akan semakin menurun. Hal ini sesuai dengan pendapat Nizori dkk (2007) bahwa nilai keasaman dan $\mathrm{pH}$ memiliki hubungan erat dengan meningkatnya aktivitas metabolisme sehingga produksi asam laktat semakin meningkat sedangkan nilai $\mathrm{pH}$ menurun.

Rauf dkk. (2011) menyatakan bahwa peningkatan total asam yoghurt tidak selalu sesuai dengan besarnya peningkatan $\mathrm{pH}$. Kondisi ini dapat terjadi di karenakan asam laktat yang dihasilkan dalam pembuatan yoghurt merupakan asam lemah, yang memberikan efek $\mathrm{pH}$ yang kecil.

Asam laktat yang dihasilkan akan menurunkan nilai $\mathrm{pH}$ dari lingkungan pertumbuhannya dan menimbulkan rasa asam. Proses pertumbuhan starter bakteri yang diberikan pada soyghurt berawal dengan adanya peningkatan laju pertumbuhan starter bakteri $S$. thermophilus yang memproduksi asam laktat pada $\mathrm{pH}$ rendah untuk mengoptimalkan pertumbuhan $L$. bulgaricus memproduksi asam laktat yang menimbulkan penurunan $\mathrm{pH}$ (Hamman dkk., 2004).

\section{KESIMPULAN}

Kesimpulan dari penelitian ini adalah tidak ada pengaruh nyata pada penambahan sari buah nanas terhadap jumlah bakteri asam laktat (BAL) pada soyghurt. Kecenderungan adanya pengaruh nyata pada penambahan sari buah nanas terhadap nilai $\mathrm{pH}$.

\section{DAFTAR PUSTAKA}

Drake, M., Cheng, X., Tamarapu, S. dan Leenanon, B., 2000, Soy protein fortification affects sensory, chemical, and microbiological properties of dairy yogurts, Journal of Food Science, 65(7): 1244-1247.

Hamman., W.,T., dan Elmer H. Marth., 2004, Survival Strptococcus thermophillus and Lactovacillus in Commercial and Expertmental Yoghurt, Journal of Food Production, Vol 47.10.781-786. 
Hidayat, I. R., Kusrahayu., Mulyani, S., 2013, Total Bakteri Asam Laktat, Nilai pH dan Sifat Organoleptik Drink Yoghurt dari Susu Sapi yang Diperkaya Dengan Ekstrak Buah Mangga, Animal Agriculture Journal, Vol. 2. No. 1, 2013, p 160167, Fakultas Peternakan dan Pertanian Universitas Diponegoro Semarang.

Irkin, R., dan Eren, U.V., 2008, Research about viable Lactobacillus bulgaricus and Streptococcuc thermophylus number \& food science in the market yoghurt, World J. of Dairy 3(1): 25-28.

Jannah, A. M., Anang, M. L., Yoyok, B. P., Ahmad, N. A., Setya, B. M. A., 2014, "Total Bakteri Asam Laktat, pH, Keasaman, Citarasa dan Kesukaan Yoghurt Drink dengan Penambahan Ekstrak Buah Belimbing", Jurnal Aplikasi Pangan 3(2) 2014, Indonesian Food Technologists.

Kumalasari, K.E.D, Nurwantoro, dan S. Mulyani., 2012, Pengaruh Kombinasi Susu dengan Air Kelapa Terhadap Total Bakteri Asam Laktat (BAL), Total Gula, dan Keasaman Drink Yoghurt, Jurnal Aplikasi Teknologi Pangan, 1 (2): 48-53.

Lesbani, A., Yuliasari, N., Riyanti, F., Loekitowati H, P., dan, Yusuf, S., 2014, Pembinaan Industri Kecil Sari Buah Nanas dan Nutri Jelly sebagai Pengolahan Alternatif dari Buah Nanas dengan Kandungan Gizi yang Tinggi di Desa Beti Inderalaya Selatan KAB. Organ Ilir, Jurnal Pengabdian Sriwijaya.

Mulyani, S., A. M. Legowo, dan A. A. Mahanani., 2008, Viabilitas bakteri asam laktat, keasaman dan waktu pelelehan es krim probiotik menggunakan starter Lactobacillus casei dan Bifidobacterium bifidum, J. Indon. Trop. Anim. Agric. 33 (2) : 120-125.

Nizori.A, Suwita. V, Surhaini, Mursalin, Melisa, Sunarti. T.C, dan E. Warsi. E. 2007. Pembuatan soyghurt sinbiotik sebagai makanan fungsional dengan penambahan kultur campuran Streptococus thermophilllls, Lactobacillus bulgaricus dan Lactobacillus acidophilus. Program Studi Teknologi Hasil Pertanian. Fakultas Pertanian,Universitas Jambi.

Prayitno., 2006, The content of lactic acid and lactose of yoghurt fermented with different number and percentage starter bacteria, J. Anim, Product. Fakultas Peternakan Universitas Jenderal Soedirman, Purwokerto. 8 (2) : 131-136.

Rauf, R., Widowati, D. dan Widodo, A., 2011, Sifat fisik dan kimia yoghurt yang dibuat dari tepung kedelai. Prosiding A, Seminar Nasional "Membangun Daya Saing Produk Pangan Berbasis Bahan Baku Lokal”: 68-75.

Rauf, R., dan Sarbini, D., 2012, Pengaruh Penstabil Terhadap Sifat Fisiko-Kimia Yoghurt yang Dibuat Dari Tepung Kedelai Rendah Lemak. Seminar Nasional IX Pendidikan Biologi FKIP UNS.

Shah, N. P., 2000, Probiotic bacteria : selective enumeration and survival in dairy foods, J. Dairy Sci. 83 : 894-907. 
Surono, I. S., 2004, Probiotik Susu Fermentasi dan Kesehatan. YAPMMI, Jakarta.

Uzzan, M. dan labuza, T., 2004, Critical issues in R and D of soy isoflavone-enriched foods and dietary supplements, Journal of Food Science, 69 (3): CRH77CRH86.

Wahyudi, M. 2006. Proses pembuatan dan analisis mutu yoghurt. Buletin Teknik Pertanian. 11 (1): 12-16. 